UDC 911.5:913(477)

Viktor Mykolaiovych Samoilenko,

Doctor of Science (Geography), Professor, Chair of Physic Geography and Geoecology, Taras Shevchenko National University of Kyiv, 2A Glushkov Prospekt, Kyiv, 03680, Ukraine, e-mail: viksam1955@gmail.com, https://orcid.org/0000-0002-0327-1477;

Volodymyr Ivanovych Osadchyi,

Doctor of Science (Geography), Corresponding Member of National Academy of Sciences of Ukraine, Director of Ukrainian Hydrometeorological Institute, National Academy of Science of Ukraine,

37 Nauky Prospect, Kyiv, 02000, Ukraine,

e-mail: osad@uhmi.org.ua, https://orcid.org/0000-0002-0428-4827;

Liubov Petrivna Vishnikina,

Doctor of Science (Pedagogy), Professor, Chair of Geography and Procedure of Its Training,

V. G. Korolenko National Pedagogic University of Poltava,

2 Ostrogradskyi St., Poltava, 36003, Ukraine,

e-mail: 1pvishnikina@gmail.com, https://orcid.org/0000-0003-0976-5512;

Ivan Oleksandrovych Dibrova,

$\mathrm{PhD}$ (Geography), Associate Professor, Chair of Physic Geography and Geoecology,

Taras Shevchenko National University of Kyiv,

e-mail: ivandibrova336@gmail.com, https://orcid.org/0000-0003-1157-6315

\title{
SHAPE OF CUMULATIVE LAND USE SYSTEMS' AREA DISTRIBUTION AS A PARAMETER OF ANTHROPOGENIC IMPACT ON LANDSCAPES
}

В. М. Самойленко, В. І. Осадий, Л. П. Вішнікіна, І. О. Діброва. ФОРМА КУМУЛЯТИВНОГО РОЗПОДІЛУ ПЛОЩ СИСТЕМ ЗЕМЛЕКОРИСТУВАННЯ ЯК ПАРАМЕТР АНТРОПОГЕННОГО ВПЛИВУ НА ЛАНДШАФТИ. УДосКОНАЛЕННЯ інструментарію змістового, інформаційного та розрахункового оцінювання впливу людської діяльності на довкілля $\epsilon$ наразі вельми актуальною проблемою, зважаючи на необхідність збереження і відновлення біотичного та ландшафтного різноманіття. 3 огляду на таке в статті обтрунтовано та сконструйовано класифікаційну схему кумулятивного розподілу площ систем землекористування та/або його наслідків у ландшафтах і/або фізико-географічних таксонах як аналітичний інструментарій моделювання антропогенного впливу на них. Схема базується на ідеї адекватності типів зазначеного розподілу за його формою певній категорії та інтенсивності антропогенного впливу на ландмафти чи таксони. Власне розподіл площ систем землекористування типізовано за діапазонами параметра поліноміальних трендів кумулят зазначених площ у ландшафтах або їхніх агрегаиіях. За таких умов схема кумулятивного розподілу площ оперує десятьма типами розподілу від надзвичайно опуклого до надзвичайно угнутого. Ці типи й віддзеркалюють різний антропогенний вплив на таксони -від слабкого до надзвичайно сильного. Верифікацію схеми кумулятивного розподілу площ землекористувальних систем здійснено для тестового мегарегіону - 30 фізико-географічних областей і 130 фізико-географічних районів п'яти країв зон мішаних (хвойно-цироколистяних) і широколистяних лісів і лісостепу Украӥни. Було змодельовано й проаналізовано відповідні ицирові картограми антропогенного впливу на зазначені таксони. Верифікачія засвідчила валідність запропонованих нових методичних підходів і їхні переваги над моделюванням антропогенного впливу на ландмафти за допомогою середньовиважених $i$ інших розрахункових індексів антропізаиії та схем. Розроблений модельний інструментарій та результати його верифікаиї застосовні для удосконалення методик, схем і проектів природоохоронного менеджменту рівнинних суходільних ландиафтів і їхніх агрегацій у помірних широтах.

Ключові слова: антропогенний вплив, ландмафти, фізико-географічні таксони, системи землекористування та/або його наслідків, моделювання.

В. Н. Самойленко, В. И. Осадчий, Л. П. Вишникина, И. А. Диброва. ФОРМА КУМУЛЯТИВНОГО РАСПРЕДЕЛЕНИЯ ПЛОЩАДЕЙ СИСТЕМ ЗЕМЛЕПОЛЬЗОВАНИЯ КАК ПАРАМЕТР АНТРОПОГЕННОГО ВЛИЯНИЯ НА ЛАНДШАФТЫ. Усовершенствование инструментария содержательного, информационного и расчетного оценивания влияния человеческой деятельности на окружающую среду является сейчас весьма актуальной проблемой, учитывая необходимость сохранения и восстановления биотического и ландшафтного разнообразия. С учетом этого в статье обоснована и сконструирована классификачионная схема кумулятивного распределения площадей систем землепользования и/или его последствий в ландшафтах и/или физико-географических таксонах как аналитический инструмент моделирования антропогенного влияния на них. Схема базируется на идее адекватности типов указанного распределения по его форме определенной категории и интенсивности антропогенного влияния на ландшафты или таксоны. Собственно распределение площадей систем землепользования типизировано за диапазонами параметра полиномиальных трендов кумулят указанных площадей в ландшафтах или их агрегаичях. При таких условиях схема кумулятивного распределения площадей оперирует десятью типами распределения - от чрезвычайно выпуклого до чрезвычайно вогнутого. Эти типы и отражают разное антропогенное влияние на таксоны - от слабого до чрезвычайно сильного. Верификация схемы кумулятивного распределения площзадей систем землепользования осуществлена для тестового мегарегиона - 30 физико-географических областей и 130 физико-географических районов пяти краев зоны мешаных (хвойно-широколиственных) и широколиственных лесов и лесостепи Украины. Были смоделированы и проанализированы соответствуюшие ијифровые картограммы антропогенного влияния на указанные таксоны. Верификачия засвидетельствовала валидность предложенных новых методических подходов и их преимущества над моделированием антропогенного влияния на ландшафты при помощи средневзвешенных и других расчетных индексов антропизачии и схем. Разработанный модельный инструментарий и результаты его верификации применимы для усовершенствования методик, схем и проектов природоохранного менеджмента равнинных суходольных ландмафтов и их агрегаиий в имеренных широтах.

(C) Samoilenko V. M., Osadchyi V. I., Vishnikina L. P., Dibrova I. O., 2020

https://doi.org/10.26565/2410-7360-2020-53-20 
Ключевые слова: антропогенное влияние, ландшафты, физико-географические таксоны, системы землепользования и/или его последствий, моделирование.

Statement of the problem. Current challenges address global and regional threats to biotic and landscape diversity and the urgent need for its conservation, restoration and reproduction. They make it necessary to improve the tools for conceptual, information and calculating assessment of human activities impact on the environment. This concerns, first of all, the analysis of anthropogenic impact on landscapes and/or their aggregations in the form of regional landscape structures, such as the actual physic-geographic taxons. The analysis should be aimed at managing anthropogenic impact, reducing mentioned threats and ensuring geoecologicaleconomic balanced environmental development. That is why the study of the landscape anthropization, i.e. the process of landscape transformation through human activity, and the identification of the effects of this anthropization on the environment remains the most pressing problem of geography and geoecology.

Analysis of recent research and publications. A classified retrospective analytical review of selected European and national concepts of landscape anthropization extent identification was carried out in our recent works $[1,2]$. In terms of content and thematic spatial data, available for implementation, the most relevant and open to further improving modification and integration were concepts such as:

1) the European concept of hemeroby, most fully disclosed in such modern developments as:

- the resumptive publication of Walz U. and Stein C. [3], implemented in the German land cover web-service IOER Monitor [4] and the compilation by Winter S. in [5];

- the resumptive work of Paracchini M.L. and Capitani C. [6], implemented in the system of Eurostat Statistics [7] as all-European approach;

- the regional study of Hungary by Csorba P. and Szabó S. [8] and Poland by Kiedrzynski M. et al. [9];

- case studies by Frank S. [10], Wrbka T. et al. [11], Rüdisser J. et al. [12], Mercuri A.M. \& Florenzano A. [13] and the generalization by Ellis E.C. et al. [14] and in the guidelines [15];

2) the national concept of geological-naturemanagement analysis, the variant approaches of which have been considered in a number of recent publications, in particular:

- the publication of Shyshchenko P.G. and Gavrylenko O.P. [16, 17], concerning constructivegeographic approach and the study by Grodzynskyi M.D. in the scope of landscape ecology [18];

- the monograph of Samoilenko V. and Ivanok D. [19], developing hydro-environmental approach;
- developments on a somewhat outdated agroecological approach, considered and used, for example, in the work of Kovalchuk I. et al. [20].

With such prerequisites, in our works [2, 2123], taking into account the developments $[3,4,6$, 7], the conceptual foundations were based and the procedure was developed for landscape anthropization extent analysis, interoperable for allEuropean and Ukrainian approaches to such analysis. The principal tool of the procedure is the general interoperable classified scheme of the landscape and/or physic-geographic taxons' anthropization extent, depending on the extent of anthropogenic impact on them, caused by land use and/or land cover (LULC) systems (the last as systems of land use effects) (Table 1). Such a measure of impact is categorically specified through the appropriate hemeroby degrees, geoecological positivity / negativity, and naturalness degrees of these systems. The composition of principal LULC systems by categories and subcategories is also given in Table 1 according to [2] and taking into account [3, 24].

Commonly accepted parameters for the practical implementation of Table 1 scheme, as well as any modifications of the scheme, are, first of all, the anthropization index $\left(I_{A N T} * *\right)$ of landscapes and/or taxons and the index of geoecological situation $\left(I_{G S}\right)$ in land use in them.

Anthropization index $I_{A N T} * *$ is generally calculated in percents as average-weighted by the definite areas according to the model

$$
I_{A N T} * *=\sum_{i=1}^{n} I_{A N T, C, i} \cdot s_{i},
$$

where $I_{A N T, \mathrm{C}, i}$ - the calculating partial anthropization index. It is specific for the definite calculating (i) LULC system of a landscape and/or model physic-geographic taxon (see systems in the last column of Table 1). The index $I_{A N T, \mathrm{C}, i}$ is set in percents according to operating scale of anthropization extent. Such scale has to be developed for LULC systems of a specified test or model megaregion etc., for example the scale proposed in [2]; $s_{i}$ - the total part of the calculating LULC system's area with $I_{A N T, C, i}$. This parameter is applied in fractions of a unity, provided that the total area of a landscape or taxon is equal to $1 ; n$ - the number of calculating LULC systems in the selected operating scale within boundaries of a landscape and/or physic-geographic taxon.

The so-called index of geosituation or the geosituation index $I_{G S}$ is also in use. It is calculated by the proportion

$$
I_{G S}=f\left(S_{1-3} / S_{4-7}\right),
$$


Table 1

Interoperable classified scheme of the landscape and/or physic-geographic taxons' anthropization extent, caused by the different level land use and/or land cover (LULC) systems ${ }^{1)}$

\begin{tabular}{|c|c|c|c|c|c|}
\hline \multirow{2}{*}{$\begin{array}{l}\text { Code and name } \\
\text { of landscape } \\
\text { anthropization } \\
\text { extent category } \\
\text { or subcategory }\end{array}$} & \multicolumn{3}{|c|}{$\begin{array}{l}\text { Extent of anthropogenic impact } \\
\text { for LULC systems: }\end{array}$} & \multirow{2}{*}{$\begin{array}{c}\text { Categorical } \\
\text { ranges for val- } \\
\text { ues of an- } \\
\text { thropization } \\
\text { index } I_{A N T} * * \\
\left(I_{A N T, L(H)} * *\right), \%\end{array}$} & \multirow[b]{2}{*}{$\begin{array}{l}\text { Code and name of principal } \\
\text { LULC systems }{ }^{4)}\end{array}$} \\
\hline & $\begin{array}{l}\text { Hemeroby } \\
\text { degree }^{2)}\end{array}$ & $\begin{array}{l}\text { Geoecological } \\
\text { positivity / } \\
\text { negativity }\end{array}$ & $\begin{array}{c}\text { Degree of } \\
\text { naturalness }\end{array}$ & & \\
\hline $\begin{array}{l}1-\text { Very slight } \\
\text { anthropization }\end{array}$ & Ahemerobic & $\begin{array}{l}\text { Very geo- } \\
\text { positive }\end{array}$ & Natural & $(0 \ldots 15.8]$ & $\begin{array}{l}\text { I.1 - Nature-protection sys- } \\
\text { tem (natural \& biosphere } \\
\text { reserves etc.); XII.1 - Bare } \\
\text { rock system }\end{array}$ \\
\hline $\begin{array}{l}2 \text { - Slight an- } \\
\text { thropization }\end{array}$ & Oligohemerobic & Geo-positive & $\begin{array}{l}\text { Close to natu- } \\
\text { ral }\end{array}$ & $(15.8 \ldots 28.3]$ & $\begin{array}{l}\text { I.2 - Nature-protection sys- } \\
\text { tem (national natural \& re- } \\
\text { gional landscape parks etc.); } \\
\text { II-III - Wetland and Forestry } \\
\text { systems; XII.2-3 - Sand and } \\
\text { Sparsely vegetated systems } \\
\text { etc. }\end{array}$ \\
\hline $\begin{array}{l}3 \text { - Moderate } \\
\text { anthropization }\end{array}$ & Mesohemerobic & $\begin{array}{l}\text { Moderately } \\
\text { geo-positive }\end{array}$ & Semi-natural & $(28.3 \ldots 39.2]$ & $\begin{array}{l}\text { IV - Shrubby-herbaceous } \\
\text { natural system; V.1-2 - } \\
\text { Grassland-pasture and hay- } \\
\text { making system }\end{array}$ \\
\hline $\begin{array}{l}4 \mathrm{a}-\mathrm{L} / \mathrm{c} \text { moder- } \\
\text { ate-great an- } \\
\text { thropization }\end{array}$ & $\begin{array}{c}\mathrm{L} / \mathrm{c} \beta- \\
\text { euhemerobic }\end{array}$ & \begin{tabular}{|c|} 
L/c moderate- \\
ly geo- \\
negative \\
\end{tabular} & $\begin{array}{c}\text { L/c relatively } \\
\text { far from natu- } \\
\text { ral } \\
\end{array}$ & $(39.2 \ldots 44.8]$ & $\begin{array}{l}\text { XIII.2 - Agro-forestry sys- } \\
\text { tem; XI.1 - Dirt (country) } \\
\text { roads; 0 - Water bodies }\end{array}$ \\
\hline $\begin{array}{l}4 \mathrm{~b}-\mathrm{H} / \mathrm{c} \text { mod- } \\
\text { erate-great an- } \\
\text { thropization }\end{array}$ & $\begin{array}{c}\mathrm{H} / \mathrm{c} \beta- \\
\text { euhemerobic }\end{array}$ & \begin{tabular}{|c|} 
H/c moderate- \\
ly geo- \\
negative \\
\end{tabular} & $\begin{array}{c}\mathrm{H} / \mathrm{c} \text { relatively } \\
\text { far from natu- } \\
\text { ral }\end{array}$ & $(44.8 \ldots 50.4]$ & $\begin{array}{l}\text { V.7.1.1 - Non-forest tilled } \\
\text { slightly sloping system }\end{array}$ \\
\hline $\begin{array}{l}5 \mathrm{a}-\mathrm{L} / \mathrm{c} \text { great } \\
\text { anthropization }\end{array}$ & $\begin{array}{l}\mathrm{L} / \mathrm{c} \alpha- \\
\text { euhemerobic }\end{array}$ & $\begin{array}{l}\mathrm{L} / \mathrm{c} \text { geo- } \\
\text { negative }\end{array}$ & $\begin{array}{l}\mathrm{L} / \mathrm{c} \text { far from } \\
\text { natural }\end{array}$ & $(50.4 \ldots 57.1]$ & $\begin{array}{l}\text { V.5-6 - Fruit trees and vine- } \\
\text { yard system; V.7.1.2-3 - } \\
\text { Non-forest tilled moderately } \\
\text { \& middling sloping systems; } \\
\text { VI.1 - Drainage-irrigation } \\
\text { system etc. }\end{array}$ \\
\hline $\begin{array}{l}5 b-\mathrm{H} / \mathrm{c} \text { great } \\
\text { anthropization }\end{array}$ & $\begin{array}{l}\mathrm{H} / \mathrm{c} \alpha- \\
\text { euhemerobic }\end{array}$ & $\begin{array}{l}\mathrm{H} / \mathrm{c} \text { geo- } \\
\text { negative }\end{array}$ & $\begin{array}{l}\mathrm{H} / \mathrm{c} \text { far from } \\
\text { natural }\end{array}$ & $(57.1 \ldots 63.7]$ & $\begin{array}{l}\text { V.7.1.4-5 - Non-forest tilled } \\
\text { essentially and greatly slop- } \\
\text { ing systems }\end{array}$ \\
\hline $\begin{array}{l}6-\text { Very great } \\
\text { anthropization }\end{array}$ & Polyhemerobic & $\begin{array}{l}\text { Very geo- } \\
\text { negative }\end{array}$ & $\begin{array}{l}\text { Strange to } \\
\text { natural }\end{array}$ & $(63.7 \ldots 79.5]$ & $\begin{array}{l}\text { V.7.2 - Forest tilled system; VI } \\
\text { - Hydrotechnical- } \\
\text { hydromelioration system (ex- } \\
\text { cept VI.1); VII - Recreational } \\
\text { system; VIII.1 - Village system } \\
\text { etc. }\end{array}$ \\
\hline $\begin{array}{l}7-\text { Excessive } \\
\text { anthropization }\end{array}$ & Metahemerobic & $\begin{array}{l}\text { Excessively } \\
\text { geo-negative }\end{array}$ & Artificial & $(79.5 \ldots 100]$ & $\begin{array}{l}\text { VIII.2 - City-town system; } \\
\text { IX-X - Industrial- } \\
\text { construction and Mining } \\
\text { systems; XI - Transport- } \\
\text { communication system (ex- } \\
\text { cept XI.1) }\end{array}$ \\
\hline
\end{tabular}

${ }^{1)}$ According to [2, 21-23]; Abbreviation: L/c-low-categorical, H/c-high-categorical; ${ }^{2)}$ According to [3, 4] with our modification; ${ }^{3)}$ According to [6, 7] with our modification; ${ }^{4)}$ According to the operating scale in [2]

where $S_{1-3}$ - the total area of geo-positive LULC systems in a landscape and/or a physicgeographic taxon. These include set of proper systems from very to moderately geo-positive according to Table $1 ; S_{4-7}-$ the total area of geo-negative
LULC systems in a landscape etc., i.e. set of systems from low-categorical moderately geo-negative to excessively geo-negative in Table 1 .

Geosituation index values mark this situation in land use in landscapes or physic-geographic taxons 
according to a special scale developed in $[2,22]$. The seven categories of this scale cover geosituation from excessively favorable $\left(I_{G S} \geq 4.77\right)$ to catastrophic $\left(I_{G S}<0.13\right)$.

In addition, an attempt was made in [8] to construct cumulative curves of areas in Hungary's microregions by categories of hemeroby. However, the parameterization of such curves was not implemented and therefore their analysis remained at [8] at a simple descriptive level (see [2]). Also in [2] it was proposed to use the classified scheme of taxon area distribution among dominant LULC systems. The scheme substantially reflects the composition of the decreasing row for LULC dominant categories in the model taxon.

Identification of previously unsolved parts of the general problem. The analysis of the above developments on the problem, concerning the parameterization of anthropogenic impact on landscapes, confirms the following. Firstly, the averageweighted anthropization indexes according to model (1) are marked by the disadvantages of their application, which are characteristic of any mean value $([25,26])$. On the one hand, this is a low informational content of the mean value for estimating the variability of random variables distribution under study. On the other hand, structural heterogeneity of the LULC system areas' samples through the anthropization extent categories in Table 1 has an essential action on the anthropization index value. That is, if the landscape has a dominant by area particular LULC system with the anthropization extent subcategory occupying an average position in the scheme of the last one in Table 1, i.e. $4 \mathrm{a}$ or $4 \mathrm{~b}$, the total estimate of the landscape anthropization by $I_{A N T} * *$ is overvalued. This shift of estimates was demonstrated by us in $[2,21]$, when, for example, anthropization extent, simulated for certain foreststeppe physic-geographic taxons, was lesser than for some taxons of mixed forest zone. And this does not quite correspond to the regional factor conditionality of the anthropization process. Secondly, the geosituation index by (2), on the one hand, is less "structurally shifted" than the anthropization index by (1). However, on the other hand, this index $I_{G S}$ is also imperfect. In particular, in the absence of geopositive systems in Table 1 in a certain landscape or taxon, the geosituation index will be 0 , regardless of the geo-negative systems' composition, which may differ essentially. Thirdly, the above-mentioned scheme of taxon area distribution among dominant LULC systems ([2]) is more content-descriptive than strictly typological-parametric. This is due to the fact that the scheme describes the hierarchy of only the nodes of the corresponding area graphs among categories in Table 1, and not the specifics of the exact numerical ratios of such areas.
Thus, the model tools for estimating anthropogenic impact on landscapes or physic-geographic taxons need substantial improvement. Such tools should, as far as possible, informatively and effectively reflect the contributions to the integral landscape / taxon anthropization extent of all, not just area-dominant LULC systems, as well as the ratio of all these contributions.

Statement of the paper objective. The paper objective was to substantiate, develop and verify new and sufficiently informative analytical tools for modeling anthropogenic impact on landscapes and/or physic-geographic taxons. Hence the first task was to implement in the calculating scheme a hypothesis about the possibility of using the shape of cumulative LULC systems' area distribution as a parameter of anthropogenic impact on landscapes or taxons. The second task was to verify the created new calculating scheme for the physic-geographic taxons of the test megaregion. It was selected as a megaregion of zones of mixed (coniferous / broadleaved) and broad-leaved forests and forest-steppe of Ukraine according to zoning in [27]. A considerable spatial data bases for land use in this megaregion were organized in $[2,21,22]$. These data bases are informative enough, because they use modern open sources of digital spatial data. Such sources, in addition to [27], include, first of all, digital land cover maps obtained by the European Space Agency (ESA, [28]) and the National Geomatics Center of China (NGCC, [29]) from remote sensing data of satellite programs. According to $[22,27]$ the test megaregion consists of 5 physic-geographic regions called "krai" in Ukrainian, and 25 physicgeographic areas called "oblast'" in Ukrainian, which are divided into 130 physic-geographic districts or "raion" in Ukrainian (see next Fig. 6).

Presentation of methods and principal research material. The experience of our studies ([25, $26,2])$ shows that, given the suggestions in [8], the resumptive graphic solutions for the analysis of anthropogenic impact on landscapes and physicgeographic taxons can be correctly represented in the form of certain modified graphs of statistics. They are, firstly, graphs of categorical cumulation (or cumulative graphs) of LULC systems' area percents according to calculating for such categories anthropization indexes in physic-geographic taxons, namely areas and districts. Hereinafter, these graphs will be abbreviated as the cumulative graphs of LULC systems' areas in taxons or corresponding taxon graphs. They are constructed as points by the model

$$
v\left(s_{i}\right)_{C A T, j}=f\left(I_{A N T, C, C A T, j}\right),
$$

where $v\left(s_{i}\right)_{C A T, j}$ - the percents of LULC systems' areas, that are sequentially cumulated through 
anthropization extent categories (see Table 1), and which are present within a specific physicgeographic area or district, and are the part of these categories ranged in the order of the anthropization extent increasing; $I_{A N T, C, C A T, j}$ - the highest "system" $I_{A N T, \mathrm{C}, i}$ in the relevant (j) category (see (1)), which in this case is the calculating upper limit of this category.

The latter parameter should be noted as follows. On the one hand, it is defined only for categories, that is, without taking into account the subcategories of Table 1. On the other hand, according to the operating scale of landscape anthropization extent $([2,21])$ mentioned in the fourth column of Table 1 , the value $I_{A N T, C, C A T, j}$ are determined by LULC systems with the highest anthropization extent within each category. Namely: for category 1, such system is Bare rock system, the value of $I_{A N T, \mathrm{C}, i}$ for which causes the corresponding value of $I_{A N T, C, C A T, 1}=12.6 \%$; for category $2-$ Mixed forest system with $I_{A N T, C, C A T, 2}=27.7 \%$; for category $3-$ Grassland-pasture and haymaking system with $I_{A N T, C, C A T, 3}=36.0 \%$; for category $4-$ Non-forest tilled slightly sloping system with $I_{A N T, C, C A T, 4}=$ 46.7\%; for category 5 - Non-forest tilled essentially and greatly sloping system with $I_{A N T, C, C A T, 5}=$ $58.0 \%$; for category 6 - System of geo-negative hydromelioration consequences with $I_{A N T, C, C A T, 6}=$ $79.5 \%$; for category 7 - City-town system, including cities with residents' number more than 1,000 thousands of people, with $I_{A N T, C, C A T, 7}=98.7 \%$.

Secondly, it is advisable to approximate the points of cumulative graphs under the model (3) by second-order polynomial trends according to the formula

$$
\begin{gathered}
v\left(s_{i}\right)_{C A T, j}=a_{S, A R(D I S T)}\left(I_{A N T, C, C A T, j}\right)^{2}+ \\
b_{S, A R(D I S T)}\left(I_{A N T, C, C A T, j}\right),
\end{gathered}
$$

where $a_{S, A R(D I S T)}$ i $b_{S, A R(D I S T)}$ - the parameters of polynomial trends that are singular for each physic-geographic area or district.

The set of trends calculated according to the formulas (4) for the 25 physic-geographic areas and 130 districts of the test megaregion showed the fairly high reliability of all such 155 trends (see the most typical examples for the districts in Fig. 1-4). Thus, given the squared indexes of approximation reliability $R^{2}$ for these trends and according to [25], the following quality of approximation for the investigated non-linear relationships was obtained:

1) a good by reliability approximation with $R^{2}$ $>0.9$ - for trends of 14 physic-geographic areas and 60 districts;

2) a satisfactory approximation with $0.7<R^{2} \leq$
0.9 - for trends of 11 physic-geographic areas and 70 districts.

The aforementioned set of 130 regional trends in content is sufficiently informative to summarize. Therefore, as the third step of model solutions, dependences were built for this set (Fig. 5), such as

$$
a_{S, D I S T}=f\left(I_{A N T, D I S T} * *\right),
$$

where $a_{S, D I S T}$ - the parameters of the polynomial trends for the physic-geographic districts of the test megaregion from formula (4); $I_{A N T, D I S T} * *$ - the average-weighted anthropization indexes of these districts by model (1), calculated in our works [2, 21].

Dependences (5) were quite satisfactorily approximated by the logarithmic trend with $R^{2}=0.89$ according to the formula (see Fig. 5)

$$
a_{S, D I S T}=c_{a_{\mathrm{S}}} \ln \left(I_{A N T, D I S T} * *\right)-d_{a_{\mathrm{S}}},
$$

where $c_{a_{S}}$ i $d_{a_{S}}$ - the parameters of polynomial trend, at that $c_{a_{\mathrm{S}}}=10 a_{S, D I S T} *=0.05$, and $d_{a_{\mathrm{S}}}=$ $4 a_{S, D I S T} *=0.21$, where $a_{S, D I S T} *$ - the mean value $a_{S, D I S T}$ from their set by (5).

It should be noted that the sample of 130 dependencies by (5) in Fig. 5, as well as the trend by (6), which approximates it, can be considered not only megaregional, but also valid in general for plain terrestrial landscapes and physic-geographic taxons of midlatitudes. This is caused by the considerable extent the mention sample, the variability and representativeness of its members according to [25, 2] and the normalized nature of the original graphs (3), taking into account the properties of the quasiergodicity concerning the random functions of natural geosystems' parameters ([23]).

Under these conditions, the logarithmic trend (6) was transformed into a model form in order to calculate with further classification the given ranges of the parameter $a_{S}$ as a whole. This form looks like

$$
a_{S}=c_{a_{\mathrm{S}}} \ln \left(I_{A N T, L(H)} * *\right)-d_{a_{\mathrm{S}}},
$$

where $I_{A N T, L(H)} * *$ - the lower and upper limits of the ranges for values of landscape anthropization index according to Table 1 .

Further, the just mentioned values $I_{A N T, L(H)} * *$ were strictly inserted to trend (7). This made it possible to obtain, firstly, the calculating ranges of the parameter $a_{S}$ in the trends of the cumulative graphs of LULC systems' areas in taxons according to (4), combined with the corresponding anthropization extent of taxons (by Table 1). Secondly, the regularities, concerning properly the shape of the logarithmic trend (7), were additionally used for parameter- 

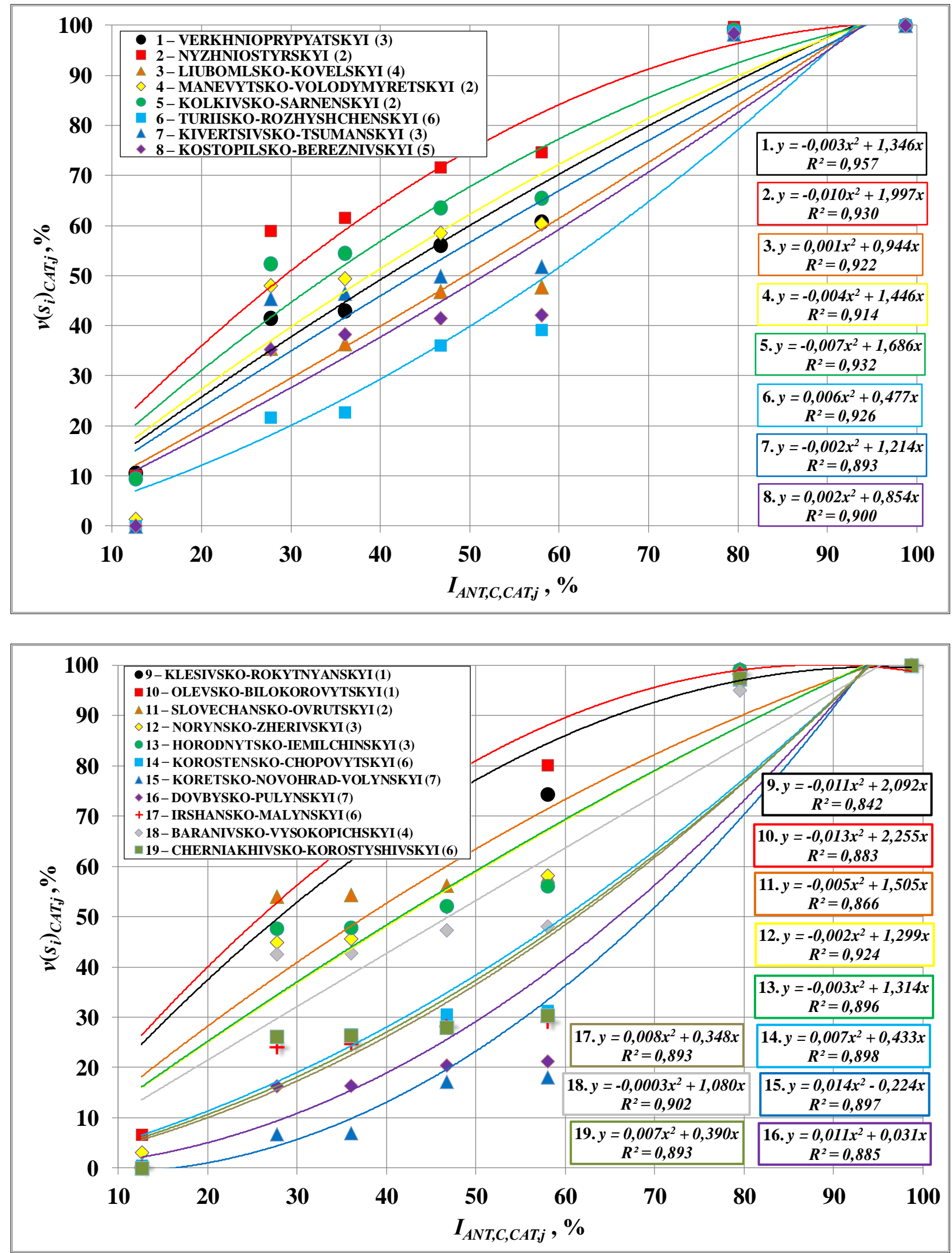

Fig. 1. Cumulative graphs of LULC systems' areas and their approximation by polynomial trends in physicgeographic districts of the Volynsko-Poliska (at the top) and the Zhytomyrsko-Poliska (at the bottom) physicgeographic areas at the Poliskyi region (see next Fig.7).

Legend: • 1 - VERHNIOPRYPYATSKYI (3) ... 19 - CHERNIAKHIVSKO-KOROSTYSHIVSKYI (6) point symbols, ordinal numbers and names ([2]) of districts and categories of anthropogenic impact on them according to Table 1 (numbers in brackets); cumulative graphs - points by model (3); trends - continuous lines by formula (4); column to the right - trend formulas for districts, $R^{2}$ - squared indexes of approximation reliability 

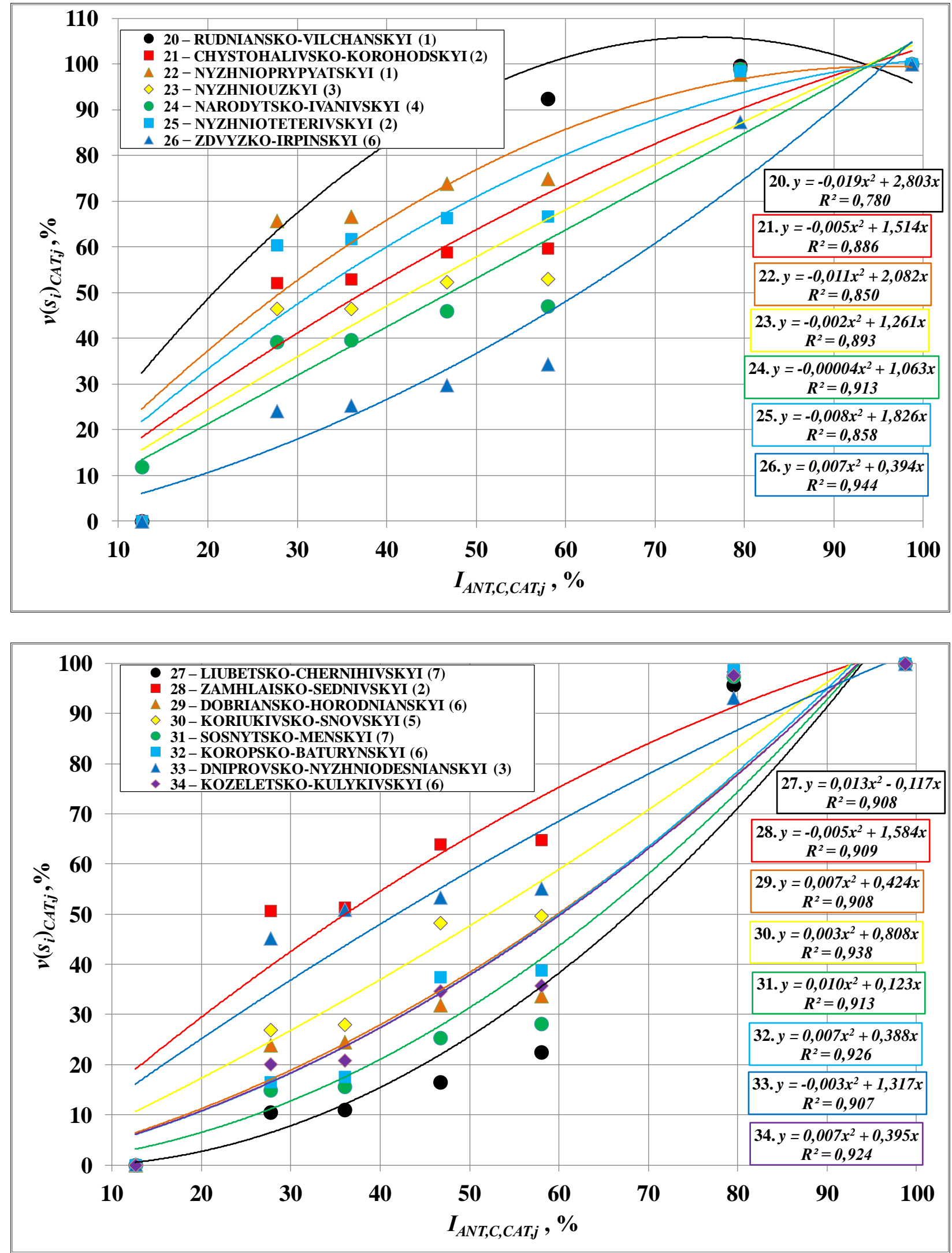

Fig. 2. Cumulative graphs of LULC systems' areas and their approximation by polynomial trends in physicgeographic districts of the Kyivsko-Poliska (at the top) and the Chernihivsko-Poliska (at the bottom) physicgeographic areas at the Poliskyi region (see next Fig.7).

Legend: • 20 - RUDNIANSKO-VILCHANSKYI (1) .. 34 - KOZELETSKO-KULYKIVSKYI (6) point symbols, ordinal numbers and names ([2]) of districts and categories of anthropogenic impact on them according to Table 1 (numbers in brackets); cumulative graphs - points by model (3); trends - continuous lines by formula (4); column to the right - trend formulas for districts, $R^{2}$ - squared indexes of approximation reliability 

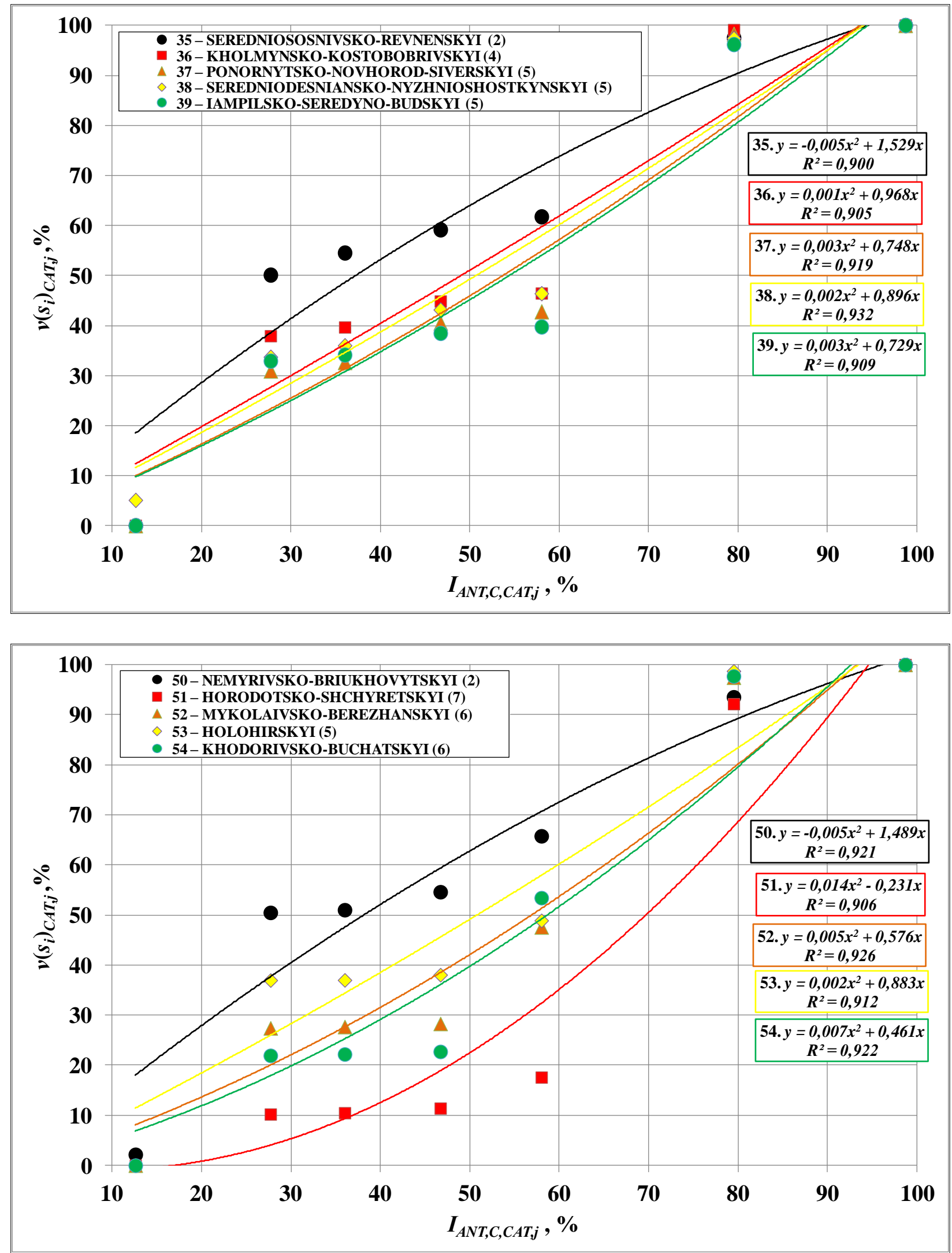

Fig. 3. Cumulative graphs of LULC systems' areas and their approximation by polynomial trends in physicgeographic districts of the Novhorod-Siversko-Poliska (at the top) and the Roztotsko-Opilska horbohirna (at the bottom) physic-geographic areas at the Poliskyi and the Zakhidnoukrainskyi regions (see next Fig.7-8). Legend: • 35 - SEREDNIOSOSNIVSKO-REVNENSKYI (2) ... 54 - KHODORIVSKO-BUCHATSKYI (6) - point symbols, ordinal numbers and names ([2]) of districts and categories of anthropogenic impact on them according to Table 1 (numbers in brackets); cumulative graphs - points by model (3); trends - continuous lines by formula (4); column to the right - trend formulas for districts, $R^{2}$ - squared indexes of approximation reliability 

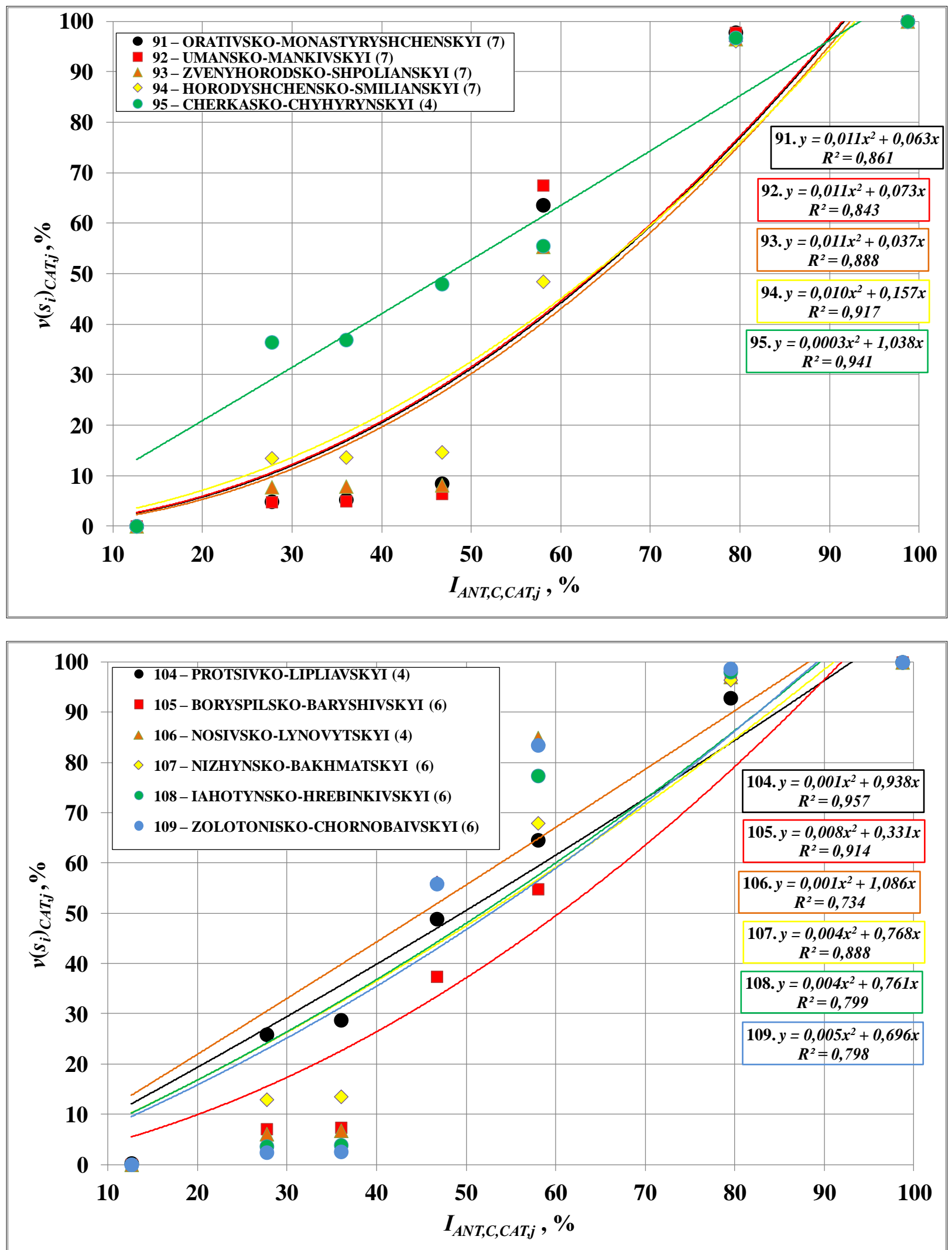

Fig. 4. Cumulative graphs of LULC systems' areas and their approximation by polynomial trends in physicgeographic districts of the Tsentralnoprydniprovska vysochynna (at the top) and the Pivnichnoprydniprovska terasova nyzovynna (at the bottom) physic-geographic areas at the Podilsko-Prydniprovskyi and the Livoberezhnodniprovskyi regions (see next Fig. 9-10)

Legend: • 91 - ORATIVSKO-MONASTYRYSHCHENSKYI (7) $\ldots \bullet 109$ - ZOLOTONISKO-

CHORNOBAIVSKYI (6) - point symbols, ordinal numbers and names ([2]) of districts and categories of anthropogenic impact on them according to Table 1 (numbers in brackets); cumulative graphs - points by model (3); trends - continuous lines by formula (4); column to the right - trend formulas for districts, $R^{2}-$ squared indexes of approximation reliability 


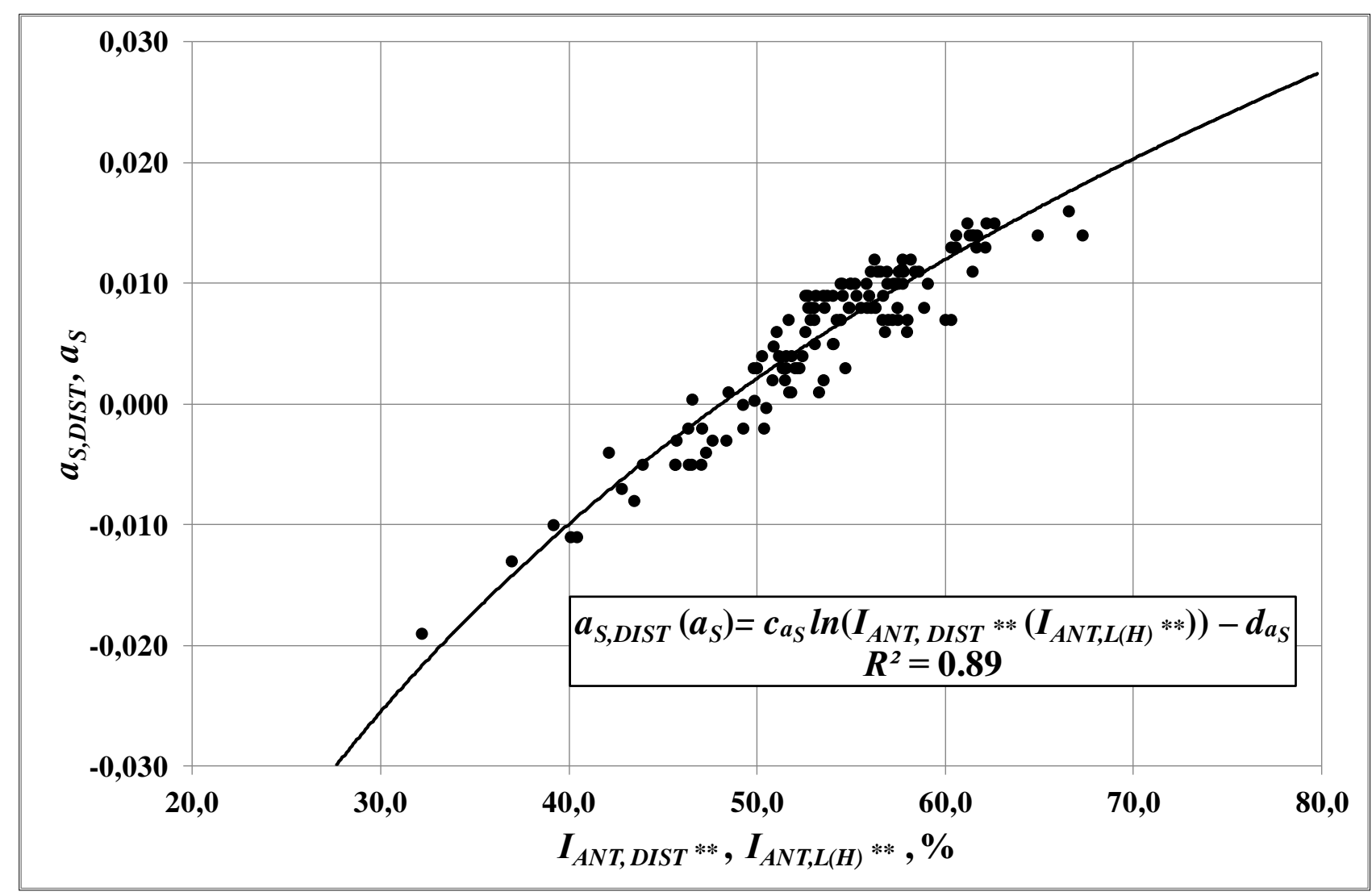

Fig. 5. Dependences (5) and their approximation by the logarithmic trend (6) in order to calculate the ranges for the parameter $a_{S}$ in Table $2\left(I_{A N T, L(H)} * *\right.$ according to Table 1; $R^{2}$ - squared index of approximation reliability)

ization, namely, the parameters of the trend shape transition from the convex through the rectilinear to the concave. This also made it possible to distinguish three levels of the corresponding ranges in the anthropization extent subcategory $4 \mathrm{~b}$, that is, as to the high-categorical moderate-great anthropization (see Table 1 and following Table 2). Thirdly, real domain of the initial districts' polynomial trends was taken into account. In particular, such consideration has made it expedient to assign the first and second categories of physic-geographic taxons' anthropization extent to the single range during parametric systematization of the trend shape. These categories' merging is explained by their essentially small territorial distribution, at that at the level of landscape aggregation lower than the physic-geographical districts (see Fig. 4.2 in [2]). Fourthly, the proposed in $[3,4]$ adequacy of taxons' anthropization extent categories to a certain intensity of anthropogenic impact on them also has been taken into account.

On such background, the final desired analytic tool was developed, directly considering the possible by shape types of trend distributions according to (4). Such a tool became a classified scheme of the LULC system areas' percent distribution in physicgeographic taxons. The scheme typifies this distribution over the ranges of the parameter $a_{S}$ in the polynomial trends of the cumulative graphs accord- ing to the formula (4). In what follows, in short, the scheme will be referred to as the classified scheme or, simply, the scheme of the LULC system areas' cumulative distribution (Table 2). It simultaneously determines the category and intensity of anthropogenic impact on taxons, corresponding to a definite distribution, as well as, of course, the extent of taxons' anthropization. The scheme of Table 2 operates with ten distribution types / impact categories: from zero type / category, namely excessively convex distribution with adequate weak anthropogenic impact, to the ninth type / category, i.e. excessively concave distribution with corresponding excessively strong impact.

The verification of the classified scheme of Table 2 was realized for the test megaregion. Verification caused the following model results (initial physic-geographic spatial data in all next figures with the digital choropleths are based on [27]).

The spatial data of choropleth in Fig. 6 indicate that only four types of the LULC system areas' cumulative distribution have been identified in the verificatory physic-geographic areas. In $60 \%$ of these areas, the type is dominated by a concave distribution with code 6 . This is adequate to the lowcategorical strong anthropogenic impact on the areas (see Table 2). This type of distribution is peculiar to most of physic-geographic areas in almost all regions, 
Classified scheme of the LULC system areas' cumulative distribution in physic-geographic taxons and adequate to the distribution categories and intensity of anthropogenic impact on taxons

\begin{tabular}{|c|c|c|c|}
\hline $\begin{array}{c}\text { Code and type of distribu- } \\
\text { tion according to the trend } \\
\text { line shape of LULC sys- } \\
\text { tem areas' cumulative } \\
\text { graphs in taxons }{ }^{1)} \text { (see } \\
(3),(4)) \\
\end{array}$ & $\begin{array}{l}\text { Ranges for } a_{S} \text { as pa- } \\
\text { rameter of formula } \\
\text { (4) trends }\end{array}$ & $\begin{array}{l}\text { Category and intensity of anthropo- } \\
\text { genic impact on taxons }{ }^{2)} \text { and the ex- } \\
\text { tent of their anthropization (code in } \\
\text { brackets according to Table 1) }\end{array}$ & $\begin{array}{l}\text { Color of anthro- } \\
\text { pogenic impact } \\
\text { category at the- } \\
\text { matic choropleths }\end{array}$ \\
\hline $\begin{array}{l}0 \text { - Excessively convex } \\
\text { distribution }\end{array}$ & $\leq-0,029$ & $0-$ Weak impact (1-2) & \\
\hline $\begin{array}{l}1-\text { Very convex distribu- } \\
\text { tion }\end{array}$ & $(-0,029 \ldots-0,011]$ & 1 - Moderate impact (3) & \\
\hline 2 -Convex distribution & $(-0,011 \ldots-0,004]$ & $\begin{array}{c}2-\mathrm{L} / \mathrm{c} \text { moderate-strong impact } \\
(4 \mathrm{a})\end{array}$ & \\
\hline $\begin{array}{l}3 \text { - Weakly convex dis- } \\
\text { tribution }\end{array}$ & $(-0,004 \ldots-0,001)$ & $\begin{array}{l}3-\mathrm{H} / \mathrm{c} \text { moderate-strong impact of } \\
\text { the } 1^{\text {st }} \text { level }(4 \mathrm{~b}-1)\end{array}$ & \\
\hline $\begin{array}{l}4 \text { - Close to rectilinear } \\
\text { distribution }\end{array}$ & {$[-0,001 \ldots 0,001]$} & $\begin{array}{l}4-\mathrm{H} / \mathrm{c} \text { moderate-strong impact of } \\
\text { the } 2^{\text {nd }} \text { level }(4 \mathrm{~b}-2)\end{array}$ & \\
\hline $\begin{array}{l}5-\text { Weakly concave dis- } \\
\text { tribution }\end{array}$ & $(0,001 \ldots 0,003]$ & $\begin{array}{l}5-\mathrm{H} / \mathrm{c} \text { moderate-strong impact of } \\
\text { the } 3^{\mathrm{d}} \text { level }(4 \mathrm{~b}-3)\end{array}$ & \\
\hline 6 - Concave distribution & $(0,003 \ldots 0,009]$ & $6-\mathrm{L} / \mathrm{c}$ strong impact $(5 \mathrm{a})$ & \\
\hline $\begin{array}{l}7 \text { - Essentially concave } \\
\text { distribution }\end{array}$ & $(0,009 \ldots 0,015]$ & $7-\mathrm{H} / \mathrm{c}$ strong impact $(5 \mathrm{~b})$ & \\
\hline $\begin{array}{l}8-\text { Very concave distri- } \\
\text { bution }\end{array}$ & $(0,015 \ldots 0,027]$ & 8 - Very strong impact (6) & \\
\hline $\begin{array}{l}9 \text { - Excessively concave } \\
\text { distribution }\end{array}$ & $>0,027$ & 9 - Excessively strong impact (7) & \\
\hline
\end{tabular}

${ }^{1)}$ Based on [2] with our modification; Abbreviation: L/c - low-categorical, H/c-high-categorical; ${ }^{2)}$ Based on [3, 4] with our modification

with the exception of the Poliskyi region. In the latter taxon a weakly convex and close to rectilinear cumulative distributions are simulated parity in two areas. The distributions correspond to the highcategorical moderate-strong anthropogenic impact of the $1^{\text {st }} 2^{\text {nd }}$ level. In six other physic-geographic areas, mostly of the Podilsko-Prydniprovskyi region, as well as the Zakhidnoukrainskyi region, the cumulative distribution by type is essentially concave. This reflects the already high-categorical strong anthropogenic impact on these taxons.

The physic-geographic districts of the test megaregion are not characterized by excessively convex and excessively concave types of distribution according to Table 2 (codes 0 and 9). Also in only one district is simulated a very concave distribution with code 8 . All this affirms the absence of districts with both weak and excessively strong anthropogenic impact on them and the limitedness of very strong such impact. Such a result is logical taking into consideration the geoecological situation in land use in the megaregion (see $[2,22]$ ).

In general, among the eight types of cumulative LULC system areas' distribution (see next Fig. 7-10) physic-geographic districts of the megaregion are characterized by such dominant types as:

- concave and essentially concave distributions. They concern, respectively, 48 or $37 \%$ and 40 or $31 \%$ of the districts and reflect the low- and highcategorical strong anthropogenic impact on the taxons;

- convex and weakly convex distributions. They each are inherent, respectively, to 11 or $8 \%$ of the districts and reflect the low- and high-categorical moderate-strong anthropogenic impact of the $1^{\text {st }}$ level on these taxons.

A more detailed analysis of districts' cumulative distribution types within the boundaries of physic-geographic regions in the test megaregion and their physic-geographic areas can be summarized as follows.

In the zone of mixed (coniferous / broad-leaved) 


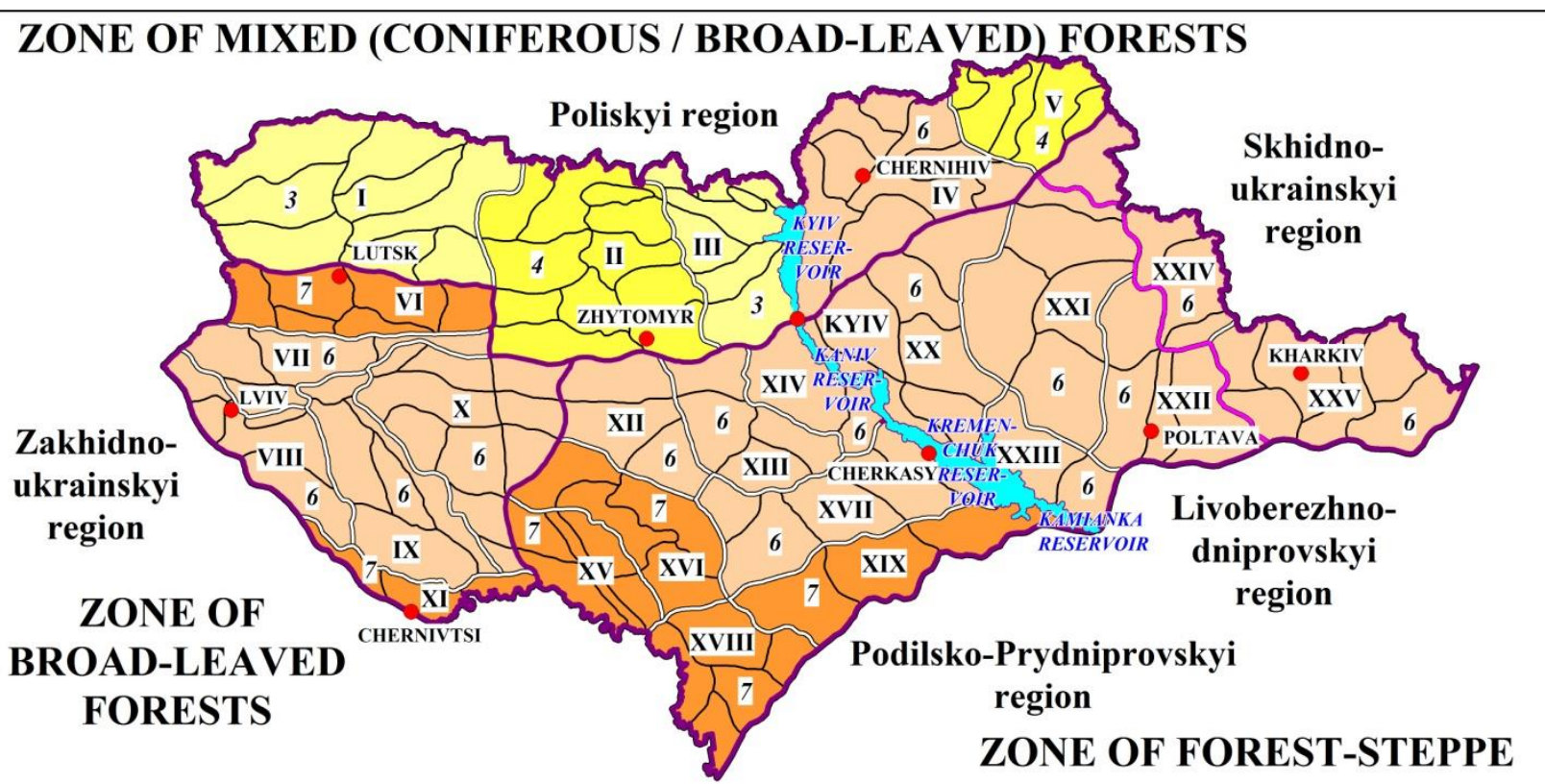

Fig. 6. Digital choropleth of the test megaregion: anthropogenic impact on the physic-geographic areas. Legend: boundaries of the physic-geographic taxons: - - zones and regions, -- regions, $=-$ areas and - - districts; I...XXV - codes of the physic-geographic areas (see Fig.7-10); 3...7 - areas' anthropogenic impact category in Table 2

forests, 39 physic-geographic districts of the Poliskyi region as a whole (Fig. 7 and Fig. 1-3) are most characterized by convex and concave cumulative distributions. Each of them is inherent to $21 \%$ of the megaregional districts and, accordingly, affirms the low-categorical moderate-strong and strong anthropogenic impact on these districts. Only in this region, in the absence of a very concaved district distribution, a very convex cumulative distribution (code 1 by Table 2 ) is logically simulated. It reflects a moderate anthropogenic impact on four geoecological-positive districts of the ZhytomyrskoPoliska and Kyiv-Poliska physic-geographic areas. Among these districts, respectively, are the Klesivsko-Rokytnyansky, the Olevsko-Bilokorovytskyi, the Rudniansko-Vilchansky and the Nyzhnioprypyatskyi districts, located in the north of these areas (see Fig. 1-2 and Fig. 7). Districts of the Poliskyi region with weakly convex (code $3,15 \%$ ) and weakly concave (code 5,13\%) cumulative distributions of LULC system areas has quite considerable quantity. That is, the former fall under the highcategorical moderate-strong anthropogenic impact of the $1^{\text {st }}$ level, and the latter - under the same impact, however of the $3^{\mathrm{d}}$ level.

The Zakhidnoukrainskyi region of the broadleaved forest zone is characterized by the fact that 33 of its physic-geographic districts are inherent, firstly, to only 6 of 8 types of megaregional cumulative distributions in the absence of types 1 and 3 (Fig. 8). That is, in this region there are no districts with moderate and high-categorical moderate-strong anthropogenic impact of the $1^{\text {st }}$ level. Secondly, only three districts with convex distribution are distinguished by a relatively small anthropization extent (code 2 in Table 3.5). These are the SmihivskoSlavutskyi, the Nemyrivsko-Briukhovytskyi and the Medzhybizko-Derazhnianskyi districts with lowcategorical moderate-strong anthropogenic impact on them. Thirdly, the Zakhidnoukrainskyi region is dominated by districts (45\%), which fell under the high-categorical impact, i.e. with an essentially concave distribution of LULC system areas (code 7 according to Table 2). The low-categorical strong impact (code $6,24 \%$ of districts of the region) and the high-categorical moderate-strong impact of the $3^{\mathrm{d}}$ level (code 5, 15\%) on the districts are also quite widespread. These districts are thus characterized by a concave and weakly concave cumulative distribution. It is infrequent for districts of the region to have close to rectilinear (code 4) and very concave (code 8) the LULC system areas' cumulative distributions relating to one district each.

Turning to the characteristics of the foreststeppe zone, the following should be noted. The first region of this zone - the Podilsko-Prydniprovskyi is characterized by very low variability of the cumulative distributions of LULC system areas in the 31 physic-geographic districts of the region (Fig. 9). Three types of cumulative distributions are simulated here. Among them an essentially concave distribution is dominated (code 7 according to Table 2). It covers $65 \%$ of the regional districts and indicates the high-categorical strong anthropogenic impact on them. And only one physic-geographic district of the region is characterized by relatively more mode- 


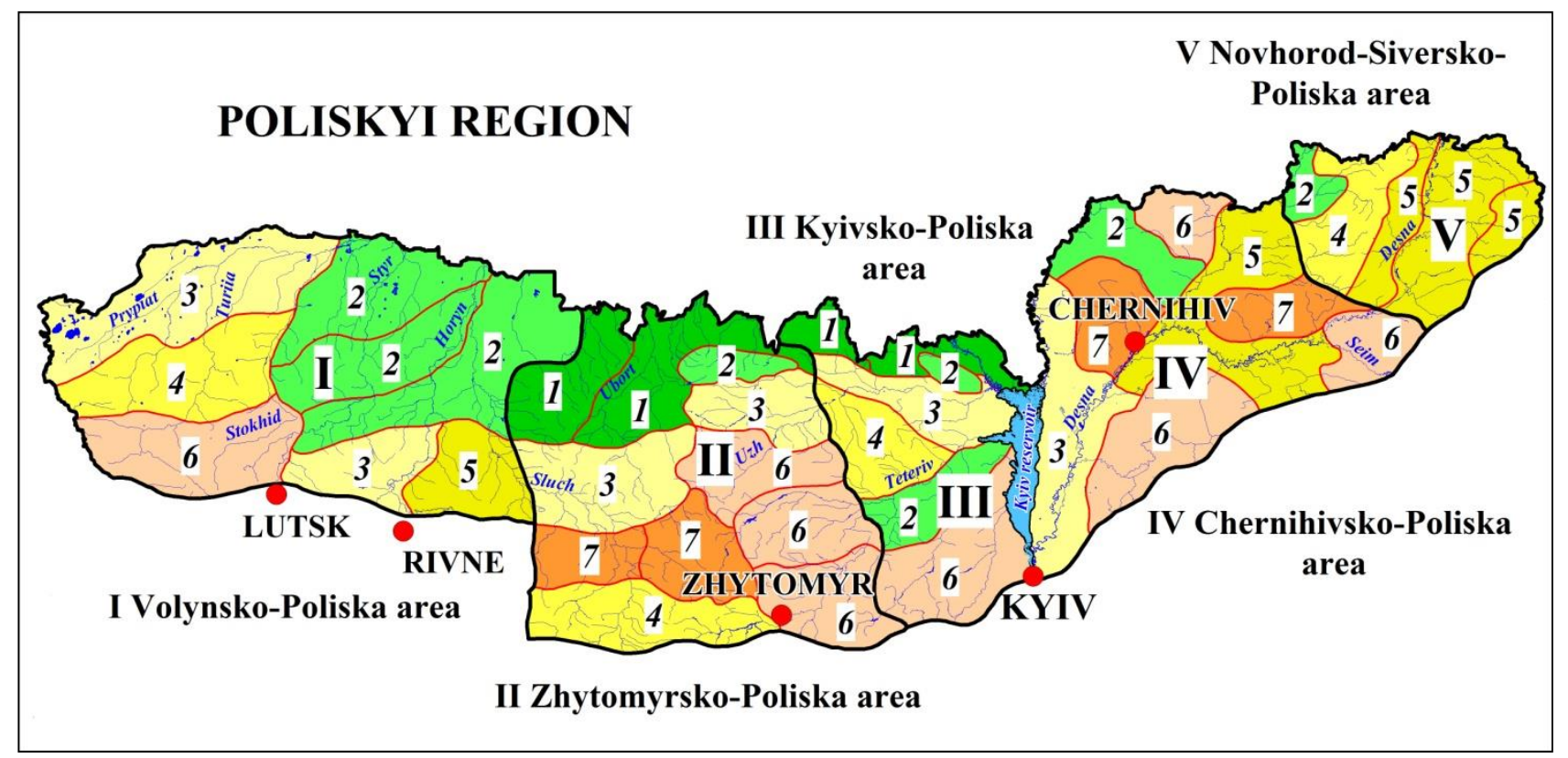

Fig. 7. Digital choropleth of the anthropogenic impact on the physic-geographic districts of the Poliskyi region. Legend: boundaries of the physic-geographic taxons: - - region and areas, - - districts; I...V - codes of the physic-geographic areas; $1 . . .7$ - districts' anthropogenic impact category in Table 2

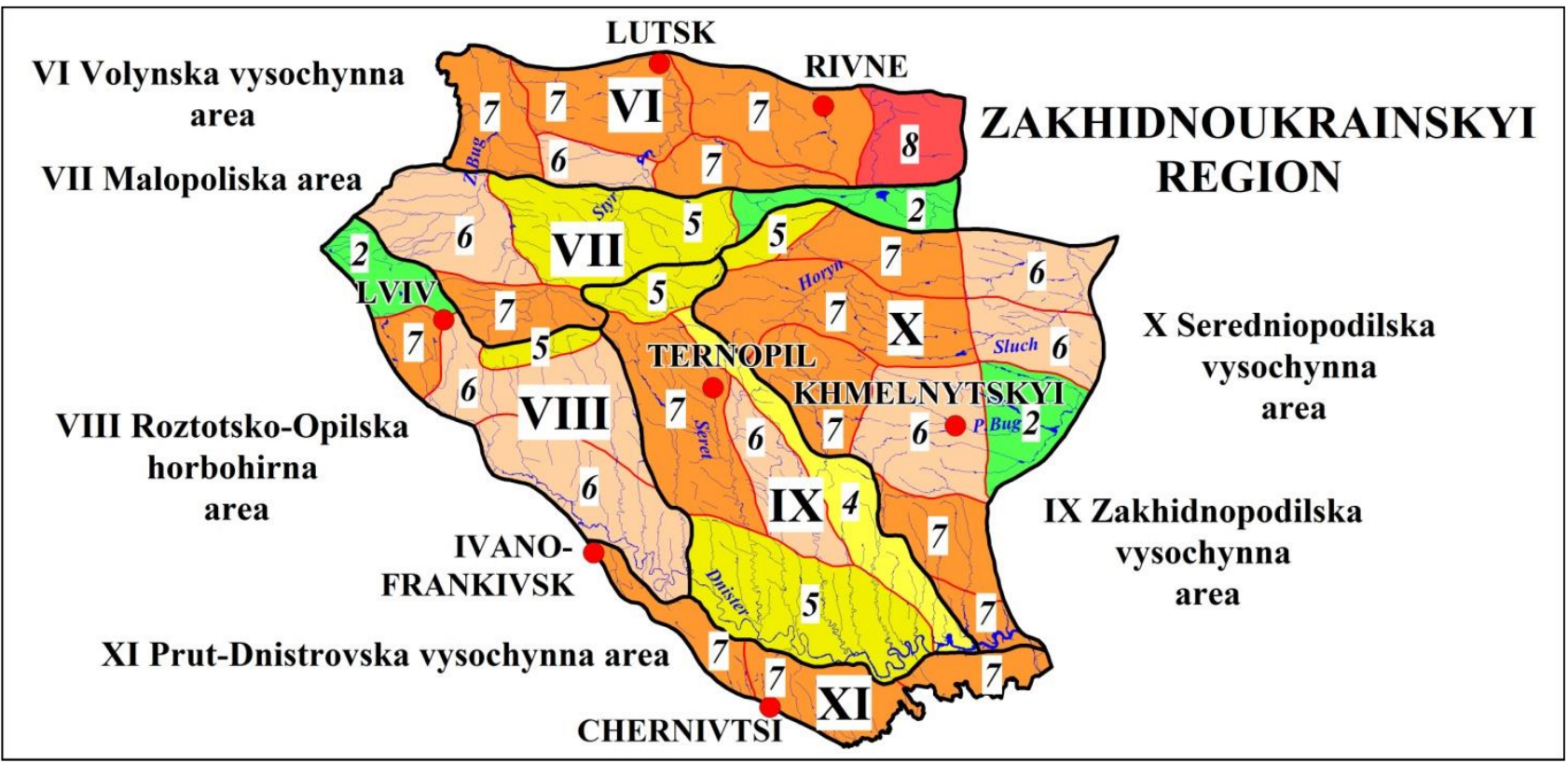

Fig. 8. Digital choropleth of the anthropogenic impact on the physic-geographic districts of the Zakhidnoukrainskyi region.

Legend: boundaries of the physic-geographic taxons: - - region and areas, - - districts; VI...XI - codes of the physic-geographic areas; $\mathbf{2} . . .8$ - districts' anthropogenic impact category in Table 2

rate anthropization. This is the CherkaskoChyhyrynskyi district with close to rectilinear distribution (see Fig. 4), which is adequate to the highcategorical moderate-strong anthropogenic impact of the $2^{\text {nd }}$ level.

The Livoberezhnodniprovskyi region (Fig. 10) is characterized by a slightly greater variability of the cumulative distribution types than in the previous region. Four such types are simulated here for
17 districts of the region. Among them, a concave distribution is prevalent, concerning $76 \%$ of the districts and marking the low-categorical strong anthropogenic impact on them (code 6 in Table 2). The less unfavorable geoecological situation was simulated in only four other districts of the region. Among them, the Konotopsko-Putyvlskyi district is 'the leader' with weakly convex type of distribution and therefore with high-categorical moderate-strong 


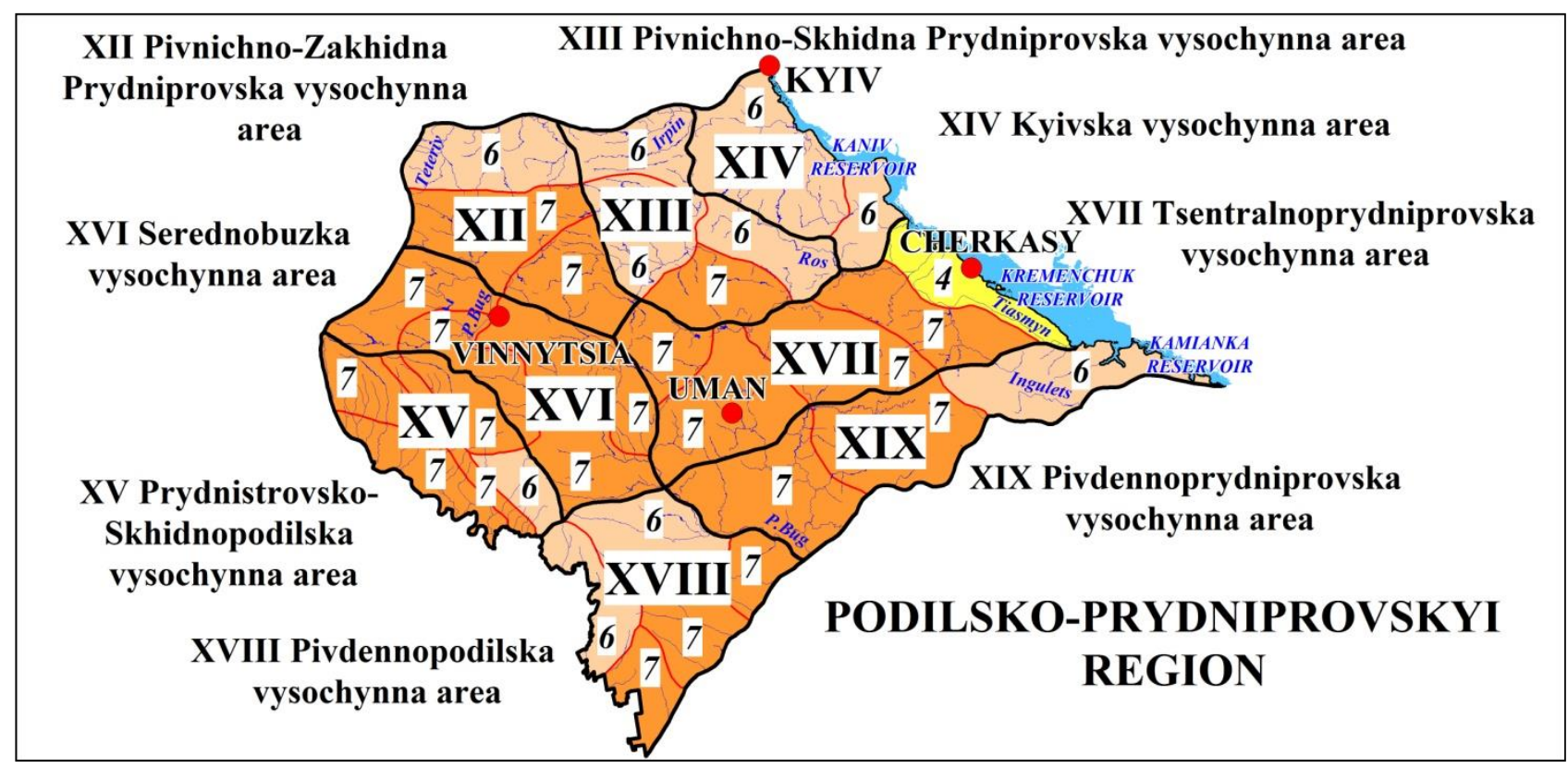

Fig. 9. Digital choropleth of the anthropogenic impact on the physic-geographic districts of the Podilsko-Prydniprovskyi region.

Legend: boundaries of the physic-geographic taxons: - - region and areas, - - districts; XII...XIX - codes of the physic-geographic areas; $4 . . .7$ - districts' anthropogenic impact category in Table 2

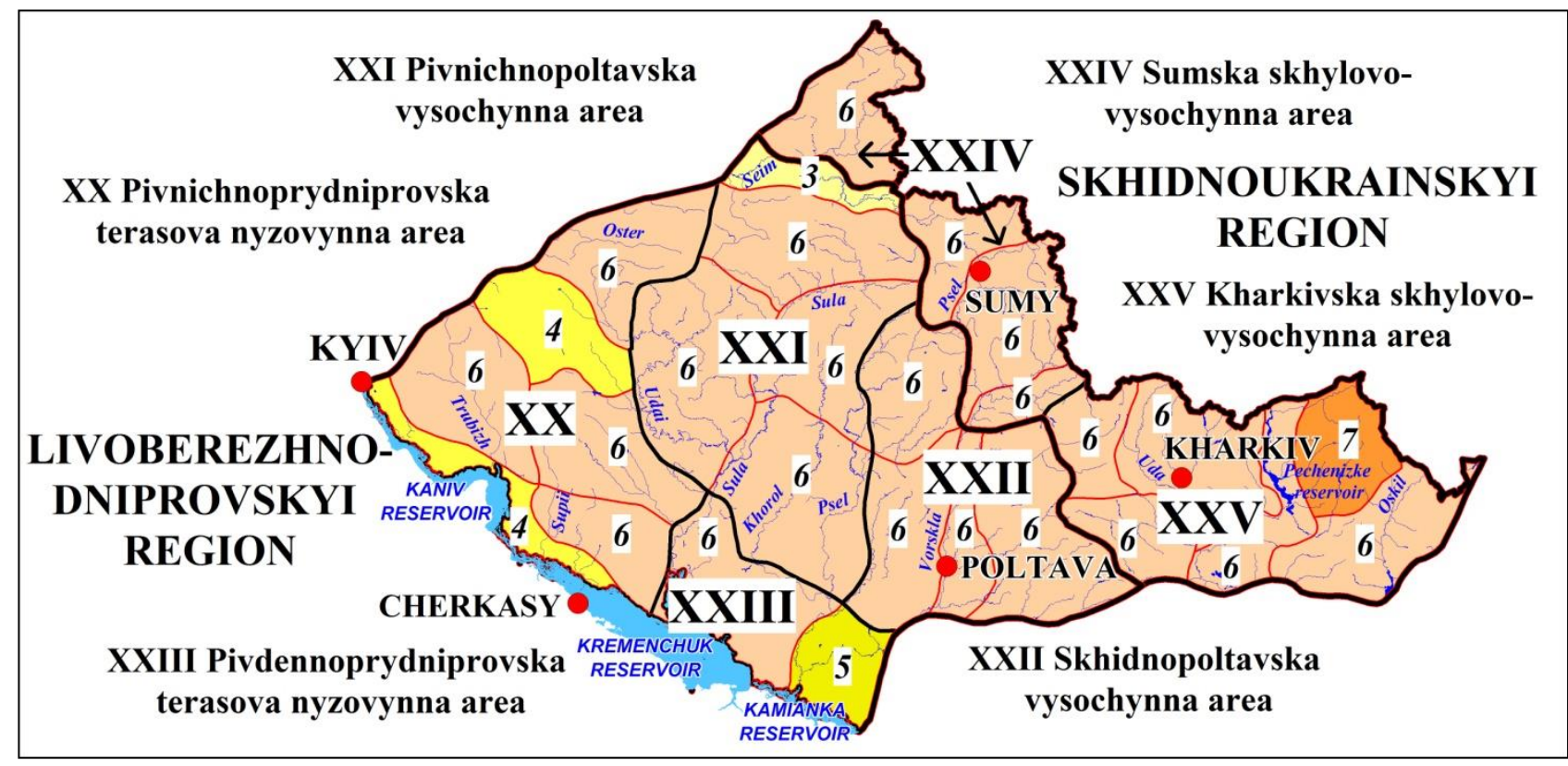

Fig. 10. Digital choropleth of the anthropogenic impact on the physic-geographic districts of the Livoberezhnodniprovskyi and the Skhidnoukrainskyi regions.

Legend: boundaries of the physic-geographic taxons: - - regions, - - areas, - - districts; $\mathbf{X X} . . . \mathbf{X V}-$ codes of the physic-geographic areas; $4 . . .7$ - districts' anthropogenic impact category in Table 2

impact of the $1^{\text {st }}$ level. The Protsivko-Lipliavskyi and the Nosivsko-Lynovytskyi physic-geographic districts are also in this list (see Fig. 4). Anthropogenic impact on them is determined as highcategorical moderate-strong of the $2^{\text {nd }} l e v e l$, which is caused by the close to rectilinear cumulative distribution (code 4 according to Table 2).

The Skhidnoukrainskyi region of the forest-step- pe zone (see Fig. 10) is essentially anthropized in the test megaregion. In ten physic-geographic districts of the region there is practically no variability of the LULC system areas' cumulative distributions. In $90 \%$ of these districts, a concave distribution is simulated, which is corresponding to the lowcategorical strong anthropogenic impact on the districts (code 6 in Table 2). And the Bilokolodiazko- 
Velykoburlutskyi district fell already under a highcategorical strong impact, which is determined by an essentially concave cumulative distribution (code 7).

In general, the above results, concerning verification of the classified scheme in Table 2 as a model analysis tool, firstly, confirm the validity of the proposed methodical approaches. Secondly, these results in content do not contradict the results of the anthropization extent simulation for the physicgeographic taxons of the same megaregion, realized in our works $[2,21,22]$ with application of the average-weighted anthropization indexes according to the model (1). However, the model results obtained and presented in Fig. 6-10 are more parametrically diverse. This is caused by the fact that the tools of Scheme 2 are more informative and statistically effective for identification of anthropogenic impact on landscapes and physic-geographic taxons than the average-weighted and other calculating anthropization indexes or schemes for consideration the impact of only dominant LULC systems.

Conclusions. The classified scheme of the land use and/or land cover (LULC) system areas' cumulative distribution in landscapes and/or physicgeographic taxons was substantiated and constructed as analytical tool for modeling anthropogenic impact on landscapes / taxons. The scheme is based on the concept that the types of the mentioned distribution in its shape are adequate a certain category and the intensity of anthropogenic impact on landscapes or taxons.

Properly the distribution of LULC system areas was typified by the ranges for the parameter of pol- ynomial trends in the cumulative graphs of these areas in landscapes or their aggregations. Under these conditions, the scheme of areas' cumulative distribution operates with ten types of distribution from excessively convex to excessively concave. These types also reflect different anthropogenic impacts on taxons - from weak to excessively strong.

Verification of the scheme calculating LULC system areas' cumulative distribution was realized for the test megaregion, including 30 physicgeographic areas and 130 physic-geographic districts of the five regions in the zones of mixed (coniferous / broad-leaved) and broad-leaved forests and forest-steppe of Ukraine. Relevant digital choropleths concerning anthropogenic impact on these taxons were simulated and analyzed. The verification affirmed the validity of the proposed new methodical approaches and their advantages over modeling of anthropogenic impact on landscapes using average-weighted and other calculating anthropization indexes and schemes.

The developed model tools and the results of its verification are applicable for the improvement of procedures, schemes and projects of environmental management for plain terrestrial landscapes and their aggregations in midlatitudes.

Prospects for further research are to realize regionalized model assessments of the conditionality and peculiarities of anthropogenic impact on physicgeographic taxons by analyzing the quasi-spectra of partial anthropization indexes and areas of LULC systems in the taxons.

\section{Bibliography}

1. Samoilenko V. Modern procedure of landscape anthropization analysis / V. Samoilenko, V. Plaskalnyi // Problems of Geography. - 2017. - Vol. 1-2. - Sofia: Bulgarian Academy of Science, National Institute of Geophysics, Geodesy and Geography. - P. 31-42. - Available at: http://geoproblems.eu/wp-content/uploads/2017/10/2017 12/2 samoilenko.pdf

2. Самойленко В.М. Антропізація ландшафтів: монографія / В.М. Самойленко, І.О. Діброва, В.В. Пласкальний. К.: Ніка-Центр, 2018. - 232 c. - Available at: http://geo.univ.kiev.ua/images/doc file/navch lit/Antropizazia\% 20landchaftiv Samoylenko.pdf

3. Walz U., Stein C. Indicators of hemeroby for the monitoring of landscapes in Germany // Journal for Nature Conservation. - 2014. - Vol. 22. - P. 279-289. - Available at: http://dx.doi.org/10.1016/j.jnc.2014.01.007

4. IOER Monitor - Monitor of Settlement and Open Space Development. - Leibniz Institute of Ecological Urban and Regional Development, 2018. - Web source: http://www.ioer-monitor.de

5. Winter S. Forest naturalness assessment as a component of biodiversity monitoring and conservation management // Forestry. - 2012. - Vol. 85, No. 2. - P. 293-304. - Available at: https://doi.org/10.1093/forestry/cps004

6. Paracchini M.L., Capitani C. Implementation of a EU wide indicator for the rural-agrarian landscape. - JRC scientific and technical reports (EUR 25114 EN-2011). - Luxembourg: Publications Office of the European Union, 2011. - 89 p. - Available at: http://dx.doi.org/10.2788/25137

7. Eurostat Statistics Explain: Agri-environmental indicator - landscape state and diversity. - 2012. - Web source: http://ec.europa.eu/eurostat/statistics-explained

8. Csorba P., Szabó S. Degree of human transformation of landscapes: a case study from Hungary // Hungarian Geographical Bulletin. - 2009. - Vol. 58. - No 2. - P. 91-99. - Available at: http://www.mtafki.hu/konyvtar/kiadv/ HunGeoBull2009/HunGeoBull_2009_2_91-99.pdf

9. Kiedrzynski M. et al. Historical Land Use, Actual Vegetation and the Hemeroby levels in ecological evaluation of an urban river valley in perspective of its rehabilitation plan // Pol. J. Environ. Stud. - 2014. - Vol. 23. - No. 1. - 
P. 109-117. - Available at: http://www.pjoes.com/Historical-Land-Use-Actual-Vegetation-r-nand-the-HemerobyLevels-in-Ecological-Evaluation,89173,0,2.html

10. Frank S. Development and Validation of a Landscape Metrics Based Approach for Standardized Landscape Assessment Considering Spatial Patterns. Statement of the PhD Candidate. - Technische Universität Dresden, 2014. - 97 p. - Available at: https://tud.qucosa.de/api/qucosa\%3A28247/attachment/ATT-1/

11. Wrbka T. et al. Linking pattern and process in cultural landscapes. An empirical study based on spatially explicit indicators // Land Use Policy. - 2004. - V.21(3). - P.289-306. - Available at: https://doi.org/10.1016/ j.landusepol.2003.10.012

12. Rüdisser J. et al. Distance to nature - A new biodiversity relevant environmental indicator set at the landscape level. - Ecological Indicators. - 2012. - V. 15. - P. 208-216. - Available at: https://doi.org/10.1016/ j.ecolind.2011.09.027

13. Mercuri A.M., Florenzano A. The Long-Term Perspective of Human Impact on Landscape for Environmental Change (LoTEC) and Sustainability: From Botany to the Interdisciplinary Approach // Sustainability. - 2019. - Vol. 11(2). - P. 413-419. - Available at: https://doi.org/10.3390/su11020413

14. Ellis E.C. et al. Used planet: a global history // Proceedings of the National Academy of Sciences of the USA. 2013. - V. 110 (Is.20). - P. 7978-7985. - Available at: https://dx.doi.org/10.1073\%2Fpnas.1217241110

15. Guidelines for land use mapping in Australia: principles, procedures and definitions. - Australian Bureau of Agricultural and Resource Economics and Sciences. - Fourth edition. - Canberra: Commonwealth of Australia, 2011. 132 p. - Available at: https://catalogue.nla.gov.au/Record/5739000

16. Шищенко П.Г., Гавриленко О.П. Геоекологічне обтрунтування проектів природокористування: підручник (ел. версія). - К. : Альтерпрес, 2014. - 414 с.

17. Шищенко П.Г., Гавриленко О.П. Конструктивно-географічні основи раціонального природокористування: підручник (ел. версія). - К.: ДП "Прінт Сервіс", 2015. - 395 с.

18. Гродзинський М.Д. Ландшафтна екологія: підручник. - К.: Знання, 2014. - 550 с.

19. Самойленко В.М., Іванок Д.В. Моделювання басейнових геосистем: монографія. - К.: ДП "Прінт Сервіс", 2015. - 208 c. - Available at: http://geo.univ.kiev.ua/images/doc file/navch lit/Samojlenko mod bas.pdf

20. Kovalchuk, I., Mykytchyn, O., \& Kovalchuk, A. (2020). Geoinformation modeling of anthropogenic transformation of the basin geosystems (case study of Dnister right tributaries) // Visnyk of V. N. Karazin Kharkiv National University. - Series "Geology. Geography. Ecology". - 2019. - Vol. 51. - P. 124-139. - Available at: https://doi.org/10.26565/2410-7360-2019-51-09

21. Samoilenko V., Dibrova I. et al. Procedure of Landscape Anthropization Extent Modeling: Implementation for Ukrainian Physic-Geographic Taxons // Environmental Research, Engineering and Management. - 2018. - Vol. 74. - No 2. - P. 67-81. - Available at: http://dx.doi.org/10.5755/j01.erem.74.2.20646

22. Samoilenko V., Dibrova I. Geoecological Situation in Land Use// Environ-mental Research, Engineering and Management. - 2019. - Vol. 75. - No 2. - P. 36-46. - Available at: http://dx.doi.org/10.5755/j01.erem.75.2.22253

23. Самойленко В.М., Діброва І.О. Природничо-географічне моделювання: підручник. - Київ: Ніка-Центр, 2019. - 320 c. - Available at: http://geo.univ.kiev.ua/images/doc_file/navch_lit/Sam_Dibrova_PG_model_2019.pdf

24. Bossard M. et al. CORINE land cover technical guide-Addendum 2000. Technical report No 40. - Copenhagen: EEA, 2000. - 105 p. - Available at: https://www.eea.europa.eu/publications/tech40add

25. Самойленко В.М. Ймовірнісні математичні методи в геоекологї: навчальний посібник. - К.: Ніка-Центр, 2002. - 404 c.

26. Topuzov O., Vishnikina L., Samoilenko V. et al. Modernization of Geographic Education at High School: Geoinformation Training Models // Information Technologies and Learning Tools. - 2019. - Vol. 73. - №5. - P. 174-184. Available at: https://doi.org/10.33407/itlt.v73i5.3190

27. Національний атлас Украӥни (електронна версія) / Інститут географії НАНУ, "ІС ГЕО", ДНВП "Картографія", ДСГКК. - 2007.

28. Climate Change Initiative Land Cover (CCI-LC) Map. - European Space Agency (ESA), 2015. - Web source: http://maps.elie.ucl.ac.be/CCI/viewer

29. Globeland30 Land Cover Map. - National Geomatics Center of China (NGCC), 2011. - Web source: http://www.globallandcover.com/GLC30Download

Author's contribution: all authors made an equal contribution to this paper. 
UDC 911.5:913(477)

\section{Viktor Samoilenko,}

Doctor of Science (Geography), Professor, Chair of Physic Geography and Geoecology, Taras Shevchenko National University of Kyiv, 2A Glushkov Prospekt, Kyiv, 03680, Ukraine, e-mail: viksam1955@gmail.com, https://orcid.org/0000-0002-0327-1477;

\section{Volodymyr Osadchyi,}

Doctor of Science (Geography), Corresponding Member of National Academy of Sciences of Ukraine, Director of Ukrainian Hydrometeorological Institute, National Academy of Science of Ukraine,

37 Nauky Prospect, Kyiv, 02000, Ukraine, e-mail: osad@uhmi.org.ua, https://orcid.org/0000-0002-0428-4827;

\section{Liubov Vishnikina,}

Doctor of Science (Pedagogy), Professor, Chair of Geography and Procedure of Its Training,

V. G. Korolenko National Pedagogic University of Poltava,

2 Ostrogradskyi St., Poltava, 36003, Ukraine,

e-mail: 1pvishnikina@gmail.com, https://orcid.org/0000-0003-0976-5512;

\section{Ivan Dibrova,}

$\mathrm{PhD}$ (Geography), Associate Professor, Chair of Physic Geography and Geoecology, Taras Shevchenko National University of Kyiv, e-mail: ivandibrova336@,gmail.com, https://orcid.org/0000-0003-1157-6315

\section{SHAPE OF CUMULATIVE LAND USE SYSTEMS' AREA DISTRIBUTION AS A PARAMETER OF ANTHROPOGENIC IMPACT ON LANDSCAPES}

Statement of the problem and paper objective. Current challenges address global and regional threats to biotic and landscape diversity and the urgent need for its conservation, restoration and reproduction. They make it necessary to improve the tools for conceptual, information and calculating assessment of human activities impact on the environment. That is why the study of the landscapes anthropization, i.e. the process of their transformation through human activity, and the identification of the effects of this anthropization on the environment remains the most pressing problem of geography and geoecology. Given this, the paper objective was to substantiate, develop and verify new and sufficiently informative analytical tools for modeling anthropogenic impact of the land use and/or land cover (LULC) system on landscapes and/or physicgeographic taxons.

Methods and results. The experience shows that the resumptive graphic solutions for the analysis of anthropogenic impact on landscapes can be correctly represented in the form of certain modified graphs of statistics. So, the classified scheme of the LULC system areas' cumulative distribution in landscapes and/or physic-geographic taxons was substantiated and constructed as analytical tool for modeling anthropogenic impact on landscapes / taxons. The scheme is based on the concept that the types of the mentioned distribution in its shape are adequate a certain category and the intensity of anthropogenic impact on landscapes or taxons. Properly the distribution of LULC system areas was typified by the ranges for the parameter of polynomial trends in the cumulative graphs of these areas in landscapes or their aggregations. Under these conditions, the scheme of areas' cumulative distribution operates with ten types of distribution - from excessively convex to excessively concave. These types also reflect different anthropogenic impacts on taxons - from weak to excessively strong.

Verification of the scheme calculating LULC system areas' cumulative distribution was realized for the test megaregion, including 30 physic-geographic areas and 130 physic-geographic districts of the five regions in the zones of mixed (coniferous / broad-leaved) and broad-leaved forests and forest-steppe of Ukraine. Relevant digital choropleths concerning anthropogenic impact on these taxons were simulated and analyzed.

Scientific novelty and practical significance. Scientific novelty is determined by the reason that the developed scheme and obtained model results are more parametrically diverse than in the existing procedures. This is caused by the fact that the proposed tools are more informative and statistically effective for identification of anthropogenic impact on landscapes and physic-geographic taxons than the averageweighted and other calculating anthropization indexes or schemes for consideration the impact of only dominant LULC systems. The verification of the developed tools for the test megaregion affirmed the general validity of the proposed new methodical approaches. The paper results are applicable for the improvement of procedures, schemes and projects of environmental management for plain terrestrial landscapes and their aggregations in midlatitudes. 
Keywords: anthropogenic impact, landscapes, physic-geographic taxons, land use and/or land cover systems, modeling.

\section{References}

1. Samoilenko V., Plaskalnyi V. (2017). Modern procedure of landscape anthropization analysis. Problems of Geography, 1-2: 31-42. Sofia: Bulgarian Academy of Science, National Institute of Geophysics, Geodesy and Geography. Available at: http://geoproblems.eu/wp-content/uploads/2017/10/2017_12/2_samoilenko.pdf

2. Samoilenko V.M, Dibrova I.O., Plaskalnyi V.V. (2018). Anthropization of Landscapes. Monograph [in Ukrainian]. Kyiv: Nika-Center, 232. Available at: http://geo.univ.kiev.ua/images/doc file/navch_lit/Antropizazia\%20landchaftiv Samoylenko.pdf

3. Walz U., Stein C. (2014). Indicators of hemeroby for the monitoring of landscapes in Germany. Journal for Nature Conservation, 22: 279-289. Available at: http://dx.doi.org/10.1016/j.jnc.2014.01.007

4. IOER Monitor (2018). Monitor of Settlement and Open Space Development. Leibniz Institute of Ecological Urban and Regional Development.Web source: http://www.ioer-monitor.de

5. Winter S. (2012). Forest naturalness assessment as a component of biodiversity monitoring and conservation management. Forestry, 85, 2: 293-304. Available at: https://doi.org/10.1093/forestry/cps004

6. Paracchini M.L., Capitani C. (2011). Implementation of a EU wide indicator for the rural-agrarian landscape. JRC scientific and technical reports (EUR 25114 EN-2011). Luxembourg: Publications Office of the European Union, 89. Available at: $\underline{\text { http://dx.doi.org/10.2788/25137 }}$

7. Eurostat Statistics (2012). Eurostat Statistics Explain: Agri-environmental indicator - landscape state and diversity. Web source: http://ec.europa.eu/eurostat/statistics-explained

8. Csorba P., Szabó S. (2009). Degree of human transformation of landscapes: a case study from Hungary // Hungarian Geographical Bulletin, 58. 2: 91-99. Available at: http://www.mtafki.hu/konyvtar/kiadv/HunGeoBull2009/ HunGeoBull_2009_2_91-99.pdf

9. Kiedrzynski M. et al. (2014). Historical Land Use, Actual Vegetation and the Hemeroby levels in ecological evaluation of an urban river valley in perspective of its rehabilitation plan. Pol. J. Environ. Stud., 23, 1: 109-117. Available at: $\quad$ http://www.pjoes.com/Historical-Land-Use-Actual-Vegetation-r-hand-the-Hemeroby-Levels-in-EcologicalEvaluation, $89173,0,2 . h$ tml

10. Frank S. (2014). Development and Validation of a Landscape Metrics Based Approach for Standardized Landscape Assessment Considering Spatial Patterns. Statement of the PhD Candidate. Technische Universität Dresden, 97. Available at: https://tud.qucosa.de/api/qucosa\%3A28247/attachment/ATT-1/

11. Wrbka T. et al. (2004). Linking pattern and process in cultural landscapes. An empirical study based on spatially explicit indicators. Land Use Policy, 21(3): 289-306. Available at: https://doi.org/10.1016/j.landusepol.2003.10.012

12. Rüdisser J. et al. (2012). Distance to nature - A new biodiversity relevant environmental indicator set at the landscape level. Ecological Indicators, 15: 208-216. Available at: https://doi.org/10.1016/j.ecolind.2011.09.027

13. Mercuri A.M., Florenzano A. (2019). The Long-Term Perspective of Human Impact on Landscape for Environmental Change (LoTEC) and Sustainability: From Botany to the Interdisciplinary Approach. Sustainability, 11(2): 413419. Available at: https://doi.org/10.3390/su11020413

14. Ellis E.C. et al. (2013). Used planet: a global history. Proceedings of the National Academy of Sciences of the USA, 110, 20: 7978-7985. Available at: https://dx.doi.org/10.1073\%2Fpnas. 1217241110

15. Guidelines for land use mapping in Australia: principles, procedures and definitions (2011). Australian Bureau of Agricultural and Resource Economics and Sciences. Fourth edition. Canberra: Commonwealth of Australia, 132. Available at: https://catalogue.nla.gov.au/Record/5739000

16. Shyshchenko P.G., Gavrylenko O.P. (2014). Geoecological rationale of environmental management projects. Textbook (el. version) [in Ukrainian]. Kyiv: Alterpress, 414.

17. Shyshchenko P.G., Gavrylenko O.P. (2015). Constructive-geographic bases of rational environmental management. Textbook (el. version) [in Ukrainian]. Kyiv: SE "Print Service", 395.

18. Grodzynskyi M.D. (2014). Landscape ecology. Textbook [in Ukrainian]. Kyiv: Znannia, 550.

19. Samoilenko V.M., Ivanok D.V. (2015). Modeling of basin geosystems. Monograph [in Ukrainian]. Kyiv: SE "Print Service", 208. Available at: http://geo.univ.kiev.ua/images/doc file/navch_lit/Samojlenko mod bas.pdf

20. Kovalchuk, I., Mykytchyn, O., \& Kovalchuk, A. (2019). Geoinformation modeling of anthropogenic transformation of the basin geosystems (case study of Dnister right tributaries). Visnyk of V. N. Karazin Kharkiv National University, Series "Geology. Geography. Ecology", 51: 124-139. Available at: https://doi.org/10.26565/2410-7360-2019-51-09

21. Samoilenko V., Dibrova I. et al. (2018). Procedure of Landscape Anthropization Extent Modeling: Implementation for Ukrainian Physic-Geographic Taxons. Environmental Research, Engineering and Management, 74, 2: 67-81. Available at: http://dx.doi.org/10.5755/j01.erem.74.2.20646

22. Samoilenko V., Dibrova I. (2019). Geoecological Situation in Land Use. Environmental Research, Engineering and Management, 75, 2: 36-46. Available at: http://dx.doi.org/10.5755/j01.erem.75.2.22253

23. Samoilenko V.M, Dibrova I.O. (2019). Natural-geographic Modeling. Textbook [in Ukrainian]. Kyiv: Nika-Center, 320. Available at: http://geo.univ.kiev.ua/images/doc file/navch_lit/Sam_Dibrova_PG_model_2019.pdf

24. Bossard M. et al. (2000). CORINE land cover technical guide-Addendum 2000. Technical report No 40. Copenhagen: EEA, 105. Available at: https://www.eea.europa.eu/publications/tech40add 
25. Samoilenko V. (2002). Probabilistic mathematical methods in geoecology. Manual [in Ukrainian]. Kyiv: NikaCenter, 404.

26. Topuzov O., Vishnikina L., Samoilenko V. et al. (2019). Modernization of Geographic Education at High School: Geoinformation Training Models. Information Technologies and Learning Tools, 73, 5: 174-184. Available at: https://doi.org/10.33407/itlt.v73i5.3190

27. National Atlas (2007). National Atlas of Ukraine (electronic version) [in Ukrainian]. Institute of Geography NASU, SRPE "Cartography" et al.

28. European Space Agency (ESA) (2015). Climate Change Initiative Land Cover (CCI-LC) Map. Web source: http://maps.elie.ucl.ac.be/CCI/viewer

29. Globeland30 Land Cover Map (2011). National Geomatics Center of China (NGCC). Web source: http://www.globallandcover.com/GLC30Download 